\title{
The Effect of Technology on Students Opinions about Authentic Learning Activities in Science Courses
}

\author{
Hilal Coskun, ${ }^{1, *,}$, Alev Dogan ${ }^{1}$, Gulsah Uluay² \\ ${ }^{1}$ Gazi Education Faculty, Division of Science Education, Department of Mathematics and Science Education, \\ Gazi University, Ankara, Turkey \\ ${ }^{2}$ Education Faculty, Division of Science Education, Department of Mathematics and Science Education, \\ Ahi Evran University, Kirsehir, Turkey
}

Copyright $\bigcirc 2017$ by authors, all rights reserved. Authors agree that this article remains permanently open access under the terms of the Creative Commons Attribution License 4.0 International License

\begin{abstract}
Today, most of the researchers have agreed on the importance of classroom environment where students responsible of their own learning. It is important to use modern learning methods with technology to reach this aim in courses. The main purpose of this study is to investigate the effect of using Technology in science courses to investigate 7th grade students' opinions about Authentic Learning and using technology in science courses. In order to achieve that, a qualitative study was administered with a total of 32 students been in 7 th grade. The study was conducted at a public secondary school during the spring term of the 2014-2015 education years in Turkey. At the beginning of the study we implemented Authentic Learning Activities that supported by technology (ALAST) in 7th grade science course for 9 weeks. These activities were "Publishing a Newspaper", "Filming a Short Movie" and "Preparing a Mini-Symposium" After implementation, semi-structured interviews were performed with small group of participants. The obtained data was evaluated by considering the context analysis of interview forms. Results of the study showed that, with ALASTs, students' opinions about authentic learning and technology usage in science class change through to a positive perspective. Students wanted to attend lesson more actively, they realized what authentic learning is and stated out that they can use technology for learning science. Also their opinions developed through using technology in school and out of school life for learning science.
\end{abstract}

Keywords Technology Based Activities, Authentic Learning, Science Education

\section{Introduction}

Technological developments have considerably impressed the educational fields [1]. Since technology can compose an integrated and interactive context to help students figure out new ideas easier than before [2]. In this context, many classroom teachers are searching for more different ways to use technology in their courses to engage students in meaningful learning environments and allow students to use and experience powerful cognitive instruments [3]. In this context, the purpose of science education is re-conceptualized and the role of educating children becomes scientifically literate, socially adept, and enthusiastic lifelong learners and authentic learning gives chance to learn lifelong [4]. In accordance with this aim, designing authentic learning activities can be used since adapting the practices of science from out of the school to classrooms can provide the advantages of authenticity for science education [5]. And also the ability to design authentic learning activities has been improved with the help of technology [6]. For instance, many instructors have experienced using technology such as computers and videos to design the real world situations in order to create authentic learning activities for students [7].

Designing an authentic science activity involves scientific thinking skills, resources that support scientific investigations and the ability to transform content [8]. But in real world, the scientific activities that students find interesting are hard to access because of activities' open-ended results and also students don't have enough courage and knowledge to edit them [5]. Because of this reason, with the help of technology, using authentic learning activities could be helpful for students. Authentic learning designs also have the potential power to improve students' educational reflections [9], [10]. For instance, multiple technologies make it possible for students to search new fields and use a variety of instruments to gather information and solve problems [2]. Technology also provides powerful tools for students to assist their learning [3].

There is limited research about authentic learning supported by technology in elementary science education. The main purpose of this study is to investigate the effect of using Authentic Learning Activities Supported by Technology (ALAST) in science courses on 7th grade students' opinions about authentic learning process in 
science courses.

\section{Literature Review}

\subsection{Authentic Learning}

In the past century, it was emphasized by researchers that education changed from focusing on the knowledge and its remembrance, to the development of knowledge, skills and attitudes [2]. Traditional education systems are often ineffective because such attempts are one-time events such as speeches or formal classroom tasks that are focused on information delivery rather than reflection of knowledge that is necessary for understanding [11]. There have been much opinions and curiosity with how to reach 21 st century learners and how to teach skills that they need in 21 st century, involving students in learning experiences retains students in their own learning environment [12].

Socio-constructivist learning theories define learning as a process that perceive learning constructive situated and collaborative [13], [14]. With the influences of constructivist philosophy and new progresses in technology on educational theories, there has been a great deal written about authentic activities in recent times, [15], [16]. Almost every conception of constructivist learning offers engaging learners in solving authentic problems [17]. [18] emphasized that;

"Learners need to have opportunities to: explore a situation with all the complexity and uncertainty of the real world, have a role in determining the task and how it might be broken up into smaller tasks, select relevant information, and find solutions that suit their needs"

Against the word 'authenticity' is mentioned in a plenty of ways in current literature about learning and curriculum, it can be consider like in the world of work, or how real workers understand and perform their various practices, each of them is used in the context of the need to explore the nature of learning in order to support students to become independent participants in some fields or disciplines [19]. Researchers generally focus on real-world, multidirectional problems and their multiple solutions that can be used role-playing exercises, problem-based activities, case studies, and participation in virtual communities of practices in authentic learning [20], [21]. Authentic learning was firstly utilized in education by [22] on account of English language learning. However today, authentic learning is not accepted only in language learning education but also in many disciplines from primary school to higher education [9].

Authentic learning is a way that lets students to deal with realistic activities using real world resources and instruments and also since they address real problems, students have chance to learn with intention by thinking and acting like professionals [23]. This kind of learning activities are devised to offer a chance to students 'real-world' experiences but the activities protect them from harmful or irrelevant consequences [19]. The authentic tasks are widely defined by educators to focus creditable $21^{\text {st }}$ century learning tendency in students, particularly in terms of motivated and engaged learning [24] and defined by [25] as "ordinary practices of the culture".

Authentic tasks also present learners the chance to investigate the problems from a variety of theoretical and practical angles, rather than a single angle that learners must simulate to be successful [27]. Qualitative studies show that the most successful learning environments with authentic activities are describing education as a process rather than a product [9].

Authentic learning environments could be helpful for students to understand and analyze authentic problems and tasks. [28] emphasized that engaging and supporting students in authentic learning tasks and environments can be helpful for students' understandings about content knowledge. The function of both an authentic learning environment and an authentic task is to show students relevance and stimulate them to develop competencies that are relevant for their future lives [2]. The educational strategies also emphasize that learning in authentic learning environments should demonstrate experiences that let students to reproduce understanding in contexts that they need to apply for understanding [4].

Also the importance of authentic learning environments can be summarized as follows: The reasons of importance and receiving attention about authenticity are knowledge and skills that are produced by learning activities are connected with the situation [5], because authentic learning environments offer a sense of personal control about what and how the learners learn [4]. An authentic learning environment does not mean that the students face authentic science laboratory with the same problems that adult scientists deal with [29], [30]. Nevertheless, in these environments, individuals have a chance to experience such a scientist and it can affect their future work choices [19], [31], [32].

Authentic learning has its own ways to literate but there is no singular standard that makes learning activities authentic [33]. Researchers have been identified ten design characteristics of authentic activities in the literature [16], [34], [35], [36], [37], [38], [39].

1. Authentic activities have real-world relevance.

2. Authentic activities are ill-defined, requiring students to define the tasks and sub-tasks needed to complete the activity.

3. Authentic activities comprise complex tasks to be investigated by students over a sustained period of time.

4. Authentic activities provide the opportunity for students to examine the task from different perspectives, using a variety of resources.

5. Authentic activities provide the opportunity to collaborate.

6. Authentic activities provide the opportunity to reflect

7. Authentic activities can be integrated and applied 
across different subject areas and lead beyond domain-specific outcomes.

8. Authentic activities are seamlessly integrated with assessment.

9. Authentic activities create polished products valuable in their own right rather than as preparation for something else.

10. Authentic activities allow competing solutions and diversity of outcome.

Authentic science education also has some characteristic particularizations. Characteristics of authentic science education are organized by [40].

"First, it would more faithfully represent the processes by which science is conducted and its results are socially accepted: it should be more historically and philosophically valid. Second, it would reflect the core element of creativity that has made science one of the major cultural achievements of humanity in recent centuries. Third, it would provide a minimalist network of ideas with which to provide satisfactory explanations of phenomena in the world-as-experienced. Lastly, it would be capable of underpinning those technological solutions to human problems that are the basis of prosperous economies, social well-being, and the health of individuals."

Against all the characteristics written upwards, researchers accentuate that it is impossible to design truly 'authentic' learning tasks and there has been a great deal of written about the differences between the tasks and problems that we face in real-world and in schools [18], [41].

\subsection{Gaps}

Using technology in classrooms is often implemented for the wrong reasons such as easiness and school administrators' pressure [3].

Some teachers are trying to find more interesting ways to integrate technology in their classes, not only a means to support students' meaningful learning, but also to enable students to engage with different powerful tools [3]. But this technology integration is limited with the teacher' way to use technology such as PowerPoint presentations, not students usage [3].

Because of didactic and outmoded educational methods, many students fail to engage with school subjects and don't want to use technology that simply replicates the one-way convey of knowledge from educator to learner; authentic learning have the ability to support student educational outcomes with the help of technology. [9].

With the effect of constructivist philosophy and new advances in technology impact on instructional theory, research and developments, there has been a growing interest about authentic activities in class [10]. [21] stated that "Connection-building will require new forms of authentic learning-forms that cut across disciplines and bring students into meaningful contact with the future employers, customers, clients, and colleagues who will have the greatest stake in their success. Without a doubt, technology will play an essential supporting role". Authentic learning activities give chances to students to understand real world problems to engage with. These problems have to address real issues [30] because;

1. The students are open to explore all angles of the problem; there is real difficulty of designing a rich problem with a consistent set of information.

2. Real problems tend to engage students more-there is a larger context of similarity with the problem.

3. Learners want to know the findings and results of the problem

Most of the reports about authentic learning now focussing on technology use in education [10], [18], [23] and [27]. Because of the reason mentioned above, students need to face authentic problems in class to engage learning more. Also as it was stated by [18], [42], it is impossible to make a learning activity truly authentic. With technology support it will be easy to design an authentic learning activity [3].

\section{Materials and Methods}

Qualitative research design was used in this study. When the relevant literature is investigated, it is seen that there isn't a common definition about qualitative research [42]. For example, according to [43] qualitative research is a process of knowledge generation that is relevant to understand individuals' life styles, individuals' behaviors, organizational structures and social change. We designed this study based on these definitions.

\subsection{Procedures}

In Turkey, Ministry of National Education plans curriculums and the Ministry programs the education activities and controls the processes [44]. In this study, we chose a course subject from $7^{\text {th }}$ grade that is termed "Structure and Characteristics of Substance" for implementing Authentic Learning Activities Supported by Technology (ALASTs). In 2009, the statement "Authentic learning supported by technology" was used by [3]. Researchers suggested that "technology presents the opportunity to employ powerful cognitive tools that can be used by students to solve complex and authentic problems". Authentic learning activities supported by technology (ALAST) are a way to use technologies to improve authentic learning activities.

According to the $7^{\text {th }}$ grade science curriculum planned by the Ministry of National Education, the course subject aims teaching structure of atom that composes of protons, neutrons and electrons; occurrence of ions that form from exchange of electrons; classification of elements, compounds and mixtures to the students. The course subject 
composes of six main topics as follows: Elements and Their Symbols, Structure of Atom, Phrase of Electrons and Chemical Properties, Chemical Bond, Compounds and Their Formulas, and Mixtures.

The reason of choosing these three activities is; giving chance students to understand real world experiences such as journalists to learn investigate a subject and publish it, film directors to see out of school and film it and scientist to understand searching a problem and share it with other scientist. Another reason was giving students a chance to experience real life with its complexity without any harm. And also with these three actives students also have the chance to integrate science into their daily life.

\subsection{Participants}

The participants in this study were $7^{\text {th }}$ grade students in a secondary public school in Turkey. Implementations are conducted with a total of 32 students during the fall 2015 semester. 17 of participants were female and 15 of them were male. All of the students were in same class. After completing the implementation process, 16 of all participants were selected randomly for interview process.

\subsection{Implementation Process}

The study was performed at a secondary school during the spring term of the 2014-2015 education years in Turkey. The required permissions have been taken from both the Ministry of National Education and the parents of the participants before starting the research. Implementations were administered after the mentioned subjects were thought by first author in stated science class.

Chemistry and computer laboratories of the school were used during the implementations. These laboratories have the required equipment like smart boards, computers, internet service etc. Besides, the computers were compatible with the software been used during the research.

The study was based on the authentic activities supported by technology (ALAST) Technology used in-class implementations recommended by [45]. During the study, the defined activities been chosen by considering the context of the chapter were applied. At this phase, two science educators and one instructor who work in the department of science education were asked for their opinions about the validity of chosen ALAST for the mentioned course subjects. These activities were "Publishing a Newspaper", "Filming a Short Movie" and "Preparing a Mini Symposium".

Implementation process continued during 9 weeks and each activity continued 3 weeks. Firstly, we arranged a 2 hour-conference for informing $7^{\text {th }}$ grade students and their parents about the process. In these conferences, we introduced the topics as follows: "What is authentic learning?", "What is Authentic Learning Activities supported by technology-ALASTs?" and "What will we do during the process?". After this conference, volunteer students attended a session. In this session, we informed students about the process, subjects of the unit and software that was necessary for activities. Then students were voluntarily divided into four collaborative study groups that include eight members.

The study consists of implementing ALASTs in the course subject. These activities were recommended by [45]. [45] recommended different activity types in terms of the integration of technology into education. Three activities from all of them were chosen and evaluated to perform in science course. Chosen activities were "Filming a Short Movie", "Publishing a newspaper" and "Preparing a mini-Symposium".

Students presented their own activities in the classroom and school. They discussed their practices and activities' contents with each other in small groups. We organized groups as mentioned above. Students rarely joined whole-class discussions. For this process, argumentative discourse activities been proposed by [46] and [47] were considered.

\subsection{Course Content}

Subject of the course was "Structure and Characteristics of Substance" unit of $7^{\text {th }}$ grade. For this subject, three different activities were implemented after the teacher completed mentioned course subject in the science class. These three ALASTs are summarized below.

\subsubsection{Publishing a Newspaper}

First activity of the study was publishing a newspaper. The aim of choosing this activity was letting students to understand how they can express their way to understand science and show it with a published newspaper. With this activity students acted like reporters and prepare a newspaper. In this newspaper, there were scientific news such as elements and their usage in daily life.

The implementation performed during 3 weeks. The course subjects towards this activity are shown in Table 1. Each student is represented with letter $\mathrm{S}$.

Table 1. Course Subject Matter for Each Group

\begin{tabular}{|c|c|}
\hline Groups & Subjects \\
\hline $\begin{array}{c}\text { Group } 1 \\
(\mathrm{~S} 1, \mathrm{~S} 2, \mathrm{~S} 3, \mathrm{~S} 4, \mathrm{~S} 5, \mathrm{~S} 6, \mathrm{~S} 7 \\
\mathrm{S} 8)\end{array}$ & $\begin{array}{ll}\text { - } & \text { Elements and Their Symbols } \\
\text { - } & \text { Structure of Atom }\end{array}$ \\
\hline $\begin{array}{c}\text { Group } 2 \\
(\mathrm{~S} 9, \mathrm{~S} 10, \mathrm{~S} 11, \mathrm{~S} 12, \mathrm{~S} 13, \mathrm{~S} 14, \\
\mathrm{S} 15, \mathrm{~S} 16)\end{array}$ & $\begin{array}{l}\text { - Phrase of Electrons and } \\
\text { Chemical Properties }\end{array}$ \\
\hline $\begin{array}{c}\text { Group } 3 \\
(\mathrm{~S} 17, \mathrm{~S} 18, \mathrm{~S} 19, \mathrm{~S} 20, \mathrm{~S} 21, \\
\mathrm{S} 22, \mathrm{~S} 23, \mathrm{~S} 24)\end{array}$ & $\begin{array}{l}\text { - Compounds and Their } \\
\text { Formulas }\end{array}$ \\
\hline $\begin{array}{c}\text { Group } 4 \\
(\mathrm{~S} 25, \mathrm{~S} 26, \mathrm{~S} 27, \mathrm{~S} 28, \mathrm{~S} 29, \\
\mathrm{S} 30, \mathrm{~S} 31, \mathrm{~S} 32) \\
\end{array}$ & $\begin{array}{ll}- & \text { Mixtures } \\
- & \text { Chemical Bond }\end{array}$ \\
\hline
\end{tabular}

The activity performed with three steps as mentioned follows:

First step: This step of the activity was educating participants about publishing a newspaper. In the process, a 1 hour-course was administered. We informed students 
about the subjects named as "What is a newspaper and How can we prepare one", "What kind of parts do a newspaper include?" and "How can be a newspaper published easily?". Also some newspaper examples were showed to students. A local journalist was invited before course and he attend the course and answered students' questions about publishing a newspaper.

Second step: This step was preparing the newspaper content. This step continued during 1 week. Each group prepared a study plan and decided a meeting to control their works. Researchers also attended to the meetings. They decided their newspaper's name and slogan first. Also they shared the duties of newspaper such as being an editor, writing an article, making an interview, taking photos, organizing data, etc. The computer laboratory of the school was used for organizing information that they collected.

Third step: Last step was gathering the data and publishing newspaper. After collecting data, each group started organizing their newspaper. At the end of study, 4 studies of 4 collaborative groups were gathered and published as one newspaper. Their newspapers' last versions' names and slogans were chosen with a competition by the students' votes. Placement of the groups' work on the paper was randomly selected.

"Publishing a Newspaper" activity process of the study is summarized in Table 2.

Table 2. Outline of Publishing a Newspaper Process

\begin{tabular}{|c|c|c|}
\hline $\begin{array}{c}\text { Education } \\
\text { (1st week) }\end{array}$ & $\begin{array}{c}\text { Procreating } \\
\text { content } \\
\text { (2nd week) }\end{array}$ & $\begin{array}{c}\text { Designing and publishing } \\
\text { newspaper (3rd week) }\end{array}$ \\
\hline $\begin{array}{c}\text { Educating } \\
\text { participants about } \\
\text { designing a } \\
\text { newspaper and } \\
\begin{array}{c}\text { using the software } \\
\text { that is necessary } \\
\text { for publishing }\end{array}\end{array}$ & $\begin{array}{c}\text { Producing and } \\
\text { collecting } \\
\text { materials such as } \\
\text { articles, } \\
\text { interviews, } \\
\text { photos for } \\
\text { newspaper. }\end{array}$ & $\begin{array}{c}\text { Organizing collected } \\
\text { materials like photos, } \\
\text { interviews, etc. on paper } \\
\text { and publishing newspaper } \\
\text { after gathering all groups } \\
\text { studies together and } \\
\text { arranging their sequence, } \\
\text { as A3 paper size. }\end{array}$ \\
\hline
\end{tabular}

\subsubsection{Filming a Short Movie}

Second activity of the study was "Filming a short movie". The aim of choosing this activity was letting students to understand how they can represent their way to understand science and film it. With this activity students acted like actors-actress, directors and filmed a short movie. In this short movie, there were scientific topics and these topics are about subjects such as atom and atom models.

In this part of the study, students pretended like a film producer. The implementation performed during 3 weeks. The course subjects towards this activity are shown in Table 3.
Table 3. Course Subject Matter for Each Group

\begin{tabular}{|c|c|}
\hline & Subjects \\
\hline $\begin{array}{c}\text { Group } 1 \text { (S1, S2, S3, S4, S5, S6, S7, } \\
\text { S8) }\end{array}$ & 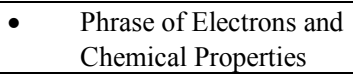 \\
\hline $\begin{array}{c}\text { Group } 2 \text { (S9, S10, S11, S12, S13, } \\
\text { S14, S15, S16) }\end{array}$ & $\begin{array}{ll}- & \text { Compounds and Their } \\
& \text { Formulas } \\
\end{array}$ \\
\hline $\begin{array}{c}\text { Group } 3 \text { (S 17, S18, S19, S20, S21, } \\
\text { S22, S23, S24) }\end{array}$ & $\begin{array}{ll}\text { - } & \text { Elements and Their } \\
& \text { Symbols } \\
\text { - } & \text { Chemical Bond }\end{array}$ \\
\hline $\begin{array}{c}\text { Group } 4 \text { (S25, S26, S27, S28, S29, } \\
\text { S30, S31, S32) }\end{array}$ & $\begin{array}{ll}- & \text { Mixtures } \\
\text { - } & \text { Structure of Atom } \\
\end{array}$ \\
\hline
\end{tabular}

The activity performed with three steps as mentioned follows:

First step: This step of the study was informing students about short movies and filming process. For this aim, we arranged a 1-hour course. At the course, we informed students about topics such as "What is short movie?", "What is short movies purpose and what we want to tell?" and "How can we will film one?". Also some samples of short movies were showed to entire class. We also informed students about using video cameras and assembling software in school computer laboratory.

Second step: This step was preparing a study plan. Each collaborative study group selected a film topic from the study subjects and wrote a script. For scripting, they had 2 meeting in the first week of Filming activity. The equipment they need was supplied by the researchers. After scripting, they started filming and it took 1 week. They also used school as a film set and students pretended like a director, actors and actresses for their movie.

Third step: Last step was assembling movie and presentation. When the filming was completed, students started assembling their short movies. The software that is necessary to assemble the movie was instructed by researcher to the groups in a 1-hour course again. It continued during 1 week. After finishing the movie assembling, short movies were showed with a premier. They also had a red carpet for the premier. School manager, teachers and students of the school were invited to the premiere.

"Filming a Short Movie Process" activity process is summarized below in Table 4.

Table 4. Outlining Filming a Short Movie Process

\begin{tabular}{|c|c|c|}
\hline $\begin{array}{c}\text { Education } \\
\text { (1st week) }\end{array}$ & $\begin{array}{c}\text { Writing script and } \\
\text { Filming the movie } \\
\text { (2nd week) }\end{array}$ & $\begin{array}{c}\text { Assembling the movie } \\
\text { and Film Premiere (3rd } \\
\text { week) }\end{array}$ \\
\hline $\begin{array}{c}\text { Educating } \\
\text { participants about } \\
\text { filming short movies } \\
\text { and using video } \\
\text { camera and the } \\
\text { software that is } \\
\text { necessary for filming }\end{array}$ & $\begin{array}{c}\text { Directing scripts of } \\
\text { the students by the } \\
\text { entire group } \\
\text { member as actors } \\
\text { and actress }\end{array}$ & $\begin{array}{c}\text { Gathering parts of the } \\
\text { movies and assembling } \\
\text { with the help of the } \\
\text { researcher and showing } \\
\text { the movie to entire } \\
\text { school with a film } \\
\text { premier. }\end{array}$ \\
\hline
\end{tabular}




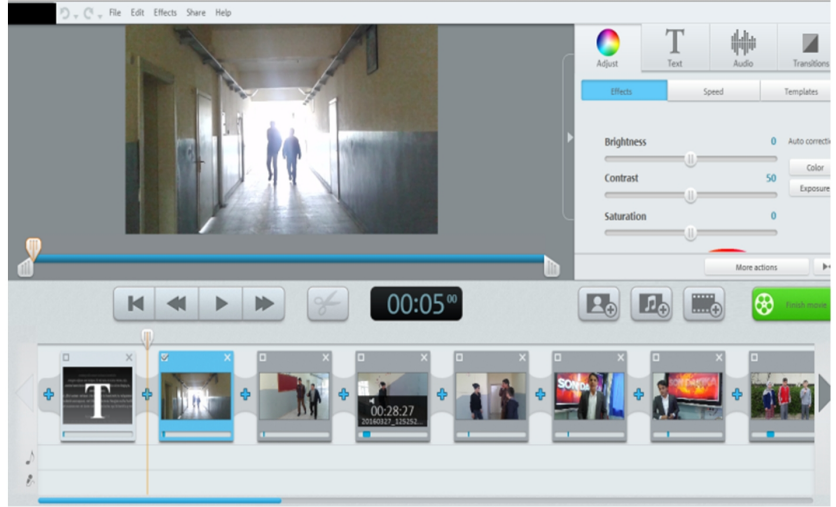

Picture 1. Assembling the movie process

\subsubsection{Preparing a Mini Symposium}

Last part of the study was preparing a mini symposium. The aim of choosing this activity was letting students to experience how they can understand science and prepare a symposium like a scientist. With this activity students acted like scientist and search for a solution for problems.

The implementation performed during 3 weeks. The course subjects towards this activity are shown in Table 5 .

Table 5. Course Subject Matter for Each Group

\begin{tabular}{|c|ll|}
\hline Groups & \multicolumn{1}{c|}{ Subjects } \\
\hline $\begin{array}{c}\text { Group 1 (S1, S2, S3, S4, } \\
\text { S5, S6, S7, S8) }\end{array}$ & $\bullet$ & Compounds and Their Formulas \\
\hline $\begin{array}{c}\text { Group 2 (S9, S10, S11, } \\
\text { S12, S13, S14, S15, } \\
\text { S16) }\end{array}$ & $\bullet$ & Elements and Their Symbols \\
\hline $\begin{array}{c}\text { Group 3 (S 17, S18, S19, } \\
\text { S20, S21, S22, S23, } \\
\text { S24) }\end{array}$ & $\bullet$ & $\begin{array}{l}\text { Mixtures } \\
\text { Chemical Bond }\end{array}$ \\
\hline $\begin{array}{c}\text { Group 4 (S25, S26, S27, } \\
\text { S28, S29, S30, S31, } \\
\text { S32) }\end{array}$ & $\bullet$ & $\begin{array}{l}\text { Structure of Atom Phrase of } \\
\text { Electrons and Chemical Properties }\end{array}$ \\
\hline
\end{tabular}

The activity performed with three steps as mentioned follows:

First step: This step was informing participants about scientific symposium with 1 hour course. In this course, we informed students about the topics "What is a symposium?", "How can we prepare a poster and present it", "How can we use libraries and online searching portals to collect data?" and "What is oral presentation?" and we showed samples of posters to students.

Second step: This step was choosing a topic to prepare a presentation and preparing posters. In the first part of the activity, they prepared a plan for their studies. Then, students started to collect data from library and online searching portals for 1 week. When collecting of data is completed, they organized their posters. They also had meetings and helped other group members' posters once a week. The posters were prepared in the format that includes students' names, the subject, data collection and references. Students used both hand writing and print-out papers on their posters.
Third step: Last step of the activity was poster presentation and oral presentation. After finishing posters, students prepared invitations for their symposiums and distributed them to the teachers and managers of school and their parents. They also invited local administer of their city. Posters were hung at a corridor of school that students named it as "Science Street". In Science Street, they had chance to see other groups' poster presentations and engaged with them. Afterwards a member of each groups presented an oral presentation. Presenters were chosen from groups by group members. When oral presentations were completed, each student got a "Participation Certificate" of their symposium that been called it "1st Young Scientist Symposium".

"Preparing a Mini Symposium" activity process of the study is summarized below in Table 6 .

Table 6. Outlining Preparing a Mini Symposium Process

\begin{tabular}{|c|c|c|}
\hline $\begin{array}{c}\text { Education } \\
(1 \text { st. week })\end{array}$ & $\begin{array}{c}\text { Library and online } \\
\text { searching } \\
(2 \mathrm{nd})\end{array}$ & $\begin{array}{c}\text { Poster presentations } \\
\text { (3rd week) }\end{array}$ \\
\hline & & $\begin{array}{c}\text { Organizing collected } \\
\text { data on posters with } \\
\text { hand writing or } \\
\text { publishing and hanging } \\
\text { posters to science street } \\
\text { of school and giving } \\
\text { away "Participant }\end{array}$ \\
$\begin{array}{c}\text { participants about } \\
\text { online and library } \\
\text { searching preparing } \\
\text { poster, scientific } \\
\text { symposiums }\end{array}$ & $\begin{array}{c}\text { Searching library } \\
\text { and online portals } \\
\text { and collect data } \\
\text { with its references }\end{array}$ & $\begin{array}{c}\text { Certificate" to students } \\
\text { and presenting each } \\
\text { groups product that was } \\
\text { chosen and answering } \\
\text { questions of guests and } \\
\text { other students }\end{array}$ \\
\hline
\end{tabular}

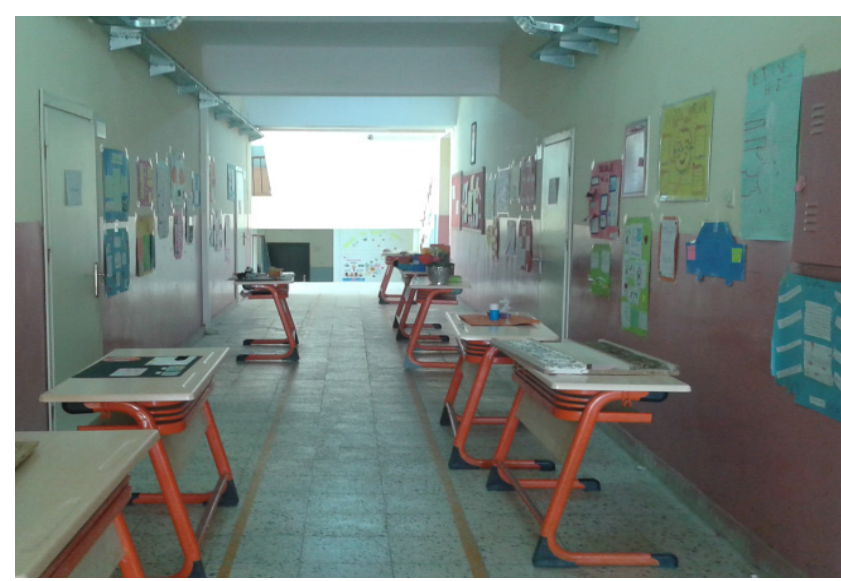

Picture 3. Symposium Street

\subsection{Data Collection}

Following step of the study was interviewing with participants. 16 students from entire participants who were volunteer to interview were selected randomly. The interviews continue during approximately 30 minutes. The interviews were recorded. The recordings were turned into texts by the researchers. 
Table 7. Interview Guide

\begin{tabular}{|c|c|}
\hline Section & Instructions \\
\hline Introduction & $\begin{array}{l}\text { Purpose of the interview } \\
\text { Explanation about confidentiality of the interview } \\
\text { Asking permission for recording }\end{array}$ \\
\hline $\begin{array}{l}\text { Interview } \\
\text { Questions }\end{array}$ & $\begin{array}{l}\text { 1. Have you ever known about publishing a newspaper, filming a short movie and preparing a mini } \\
\text { symposium or authentic learning activities before? } \\
\text { 2. You published a newspaper in science course. How did you feel because of joining to this process? } \\
\text { 3. You produced short films in science course and wrote scripts relating to the subjects. How did you feel } \\
\text { because of joining to this process? } \\
\text { 4. You participated in a symposium and you made presentations. How did you feel because of joining to } \\
\text { this process? } \\
\text { 5. Your movie was screened, you published a newspaper and you organized a symposium. How did you } \\
\text { feel when your materials were displayed? } \\
\text { 6. What do you think when you consider the entire process with ALASTs? How did ALASTs affect your } \\
\text { opinions about authentic learning, science and technology? } \\
\text { 7. What did you gain from these activities? Did the activities make your knowledge more permanent? }\end{array}$ \\
\hline Chosen Participants For Interview & $\mathrm{S} 2, \mathrm{~S} 3, \mathrm{~S} 5, \mathrm{~S} 8, \mathrm{~S} 9, \mathrm{~S} 11, \mathrm{~S} 12, \mathrm{~S} 15, \mathrm{~S} 18, \mathrm{~S} 20, \mathrm{~S} 21, \mathrm{~S} 23, \mathrm{~S} 25, \mathrm{~S} 27, \mathrm{~S} 30, \mathrm{~S} 31$ \\
\hline
\end{tabular}

\subsubsection{Interview Form}

In this study, we used semi-structured interview to collect qualitative data. Firstly, we prepared 8 questions for the interview form and four experts' opinions were taken for determining the questions that will be used in the interview. After taking the experts' advices, the number of the questions decreased to 7. After all, a semi-structured interview form that contains 7 open-ended questions was used. The interviews were conducted with 16 of all participants who were selected randomly. We received participants' permissions to record the interview process. When we completed the interviews, we turned recordings into the texts. Every answer was examined and was divided into categories and codes. The interview process is summarized in Table 7.

\section{Findings and Results}

Question 1: Have you ever known about publishing a newspaper, filming a short movie and preparing a mini symposium before?

Purpose of asking this question was understanding students' backgrounds about ALASTs. Answers of the question showed that students heard about these kinds of activities but they didn't performed before in their school life. S8's answer is given below as an example.

"Yes, of course. I know newspapers or films, but I didn't know how I can publish one or how can I direct a movie before joining these activities. Now it changed."

Question 2: You published a newspaper in science course. How did you feel because of joining to this process?

Purpose of asking this question was trying to understand students' opinions about publishing a newspaper activity and its process. Answers of question were divided into two themes. These themes were "Positive Opinions" and "Negative Opinions". There were 5 different codes in positive opinions theme and 1 code is in negative opinions theme. Analysis of the second question is summarized in the Table 8 .

Table 8. The Quantitative Analysis of the Interview Question 2

\begin{tabular}{|l|c|c|}
\hline Themes and Codes & $\mathrm{f}$ & $\%$ \\
\hline Positive Opinions & & \\
I felt happy & 16 & 100 \\
I felt excited & 12 & 75 \\
I felt like a famous reporter & 11 & 69 \\
I decided to be an editor & 4 & 25 \\
I decided to be a photographer & 1 & 7 \\
\hline Negative Opinions & 3 & 19 \\
It was boring & & \\
\hline
\end{tabular}

Analysis of the second question showed that participants had positive perspectives about publishing a newspaper. For example, they described their feelings about process with "Happy" and "Famous". They also described themselves as a famous reporter of Turkey. Another remarkable point of the analysis was students' future job choices. Some students mentioned about their desire of being an interviewer, an editor and a photographer. For instance, "I felt really happy because of joining this activity. And now I made a plan. I will be a photographer. I will take photos of wild animals and send them newspapers and magazines" is S2's answer to this question. S25's answer also has a positive perspective. This participant's answer is as follows:

"After deciding the name of our newspaper, I felt really excited, because I always wanted to be a reporter and I made it real at the end."

In contrary, S9 mentioned that she found process boring for herself because of having difficulties about using computers at the beginning of the study, but with the help of her group friends she finished her duties on time. S9's answer is given below:

"It was boring for me at the beginning, because I didn't want to spend time on computer. Also it was difficult for me to use the software. But then with the help of my friends, it changed and I began to feel happier." 
Question 3: You produced short films in science course and wrote scripts relating to the subjects. How did you feel because of joining to this process?

Purpose of asking third question was trying to understand students' opinions about filming a short movie activity and its process. Answers of question were divided into two themes. These themes were "Positive opinions" and "Negative opinions". There were 7 different codes in positive opinions theme and 2 negative codes in negative opinions theme. Analysis of the second question is summarized in the Table 9 below.

Table 9. The Quantitative Analysis of the Interview Question 3

\begin{tabular}{|l|c|c|}
\hline Themes and Codes & $\mathrm{f}$ & $\%$ \\
\hline Positive Opinions & 12 & 75 \\
I felt important & 9 & 57 \\
I felt belong to the lesson & 9 & 57 \\
I felt like a star on red carpet & 7 & 44 \\
I felt wiser about using technology & 6 & 38 \\
I felt famous like.... & 4 & 25 \\
I decided to be a director & 3 & 19 \\
I can win a short movie award & & \\
\hline Negative Opinions & 2 & 13 \\
I had difficulty & 1 & 7 \\
Time-consuming & \\
\hline
\end{tabular}

Analysis of the third question was examined and it was seen that $75 \%$ of students felt themselves important. In the interview, students stated that they felt themselves as a part of the lesson. Furthermore, they defined themselves as directors. They used "famous" director and actors/actresses to explain how they felt in the process. They also had the confidence of winning an award. S5' answer is indicated below:

"I felt important when I see our film. I think we can share it on a website. Maybe EBA (EBA is a Turkish Education Portal that can be used by teachers and students)... Maybe we can join a competition and win an award."

Other positive opinions were stated by S31 and S32 and their answers were shown below:

"I felt famous myself when our teachers celebrate me. I think I'm really talented about acting. (He smiled). When I see myself on the screen, I really felt important myself. We all like cool stars on the red carpet."

"I felt myself a part of the class when I see Element (Name of newspaper), I felt important and I have never felt so excited before coming to school, because I'm the editor, right?"

They also mentioned about the difficulties been experienced in the process because of activity. For instance, answers of S18 and S9 are cited respectively as follows:

"Oh, it was really difficult to direct a movie. It took too much time to direct a 5 minute movie.."

"We have so much homework and at first I thought that we would have more homework because of these activities. They took much time, but when I saw my friends' works, I wanted to be a part of it. I admire them. I didn't believe that it would be fun."

Question 4: You participated in a symposium and you made presentations. How did you feel because of joining to this process?

Purpose of asking fourth question was trying to understand students' opinions about preparing a mini symposium activity and its process. Answers of question were divided into two themes. These themes were "Positive Tendency" and "Negative Tendency ". Positive tendency theme has 4 different codes and 2 negative codes were found in negative themes. Analysis of the fourth question is summarized in the Table 10 below.

Table 10. The Quantitative Analysis of the Interview Question 4

\begin{tabular}{|l|c|c|}
\hline Themes and Codes & $\mathrm{f}$ & $\%$ \\
\hline Positive Tendency & & \\
I felt like a scientist & 16 & 100 \\
I felt excited & 15 & 94 \\
I felt happy & 10 & 63 \\
I was proud of myself & 9 & 57 \\
\hline Negative Tendency & & \\
My homework increased & 4 & 25 \\
It was waste of time & 2 & 13 \\
\hline
\end{tabular}

When the fourth question analysis was examined, it was seen that activities gave the students a new point of view about symposiums. The students' posters were exhibited in the symposium. All of the students stated that they felt themselves as scientist and $95 \%$ of the participants mentioned that they got very excited during the process. They emphasized that especially having a "Participation Certificate" made process more interesting. They also mentioned that they felt proud of themselves when their parents and their teachers asked questions about their presentation to them. S12 stated that "I'm about to faint when I saw my father coming from the street. He was watching me while I was answering my teacher's questions. He smiled and I have never been proud of myself this much."

Also S27's answer is illustrated as follows;

"I understand how scientists feel when they share their ideas with others. My schoolmaster asked me three questions and I easily answered them. Wow, I really felt myself as a scientist".

However, it was stated by some students that the symposium process increased their homework more. S11's opinion about the process is shown below:

"I have already had too much homework before symposium activity. These activities were enjoyable, but they also increased my homework. I think that we don't need to learn these activities and software."

Question 5: Your movie was screened, you published a 
newspaper and you organized a symposium. How did you feel when your materials were displayed?

Purpose of asking this question was trying to understand students' feelings about the ALASTs' presentations. Answers of this question were divided into two themes. These themes were "Positive Feelings" and "Negative Feelings". Positive feelings theme has 7 different codes and there is not any code in negative theme. Analysis of the 5th question is summarized in the Table 11.

Table 11. The Quantitative Analysis of the Interview Question 5

\begin{tabular}{|l|c|c|}
\hline Themes and Codes & $\mathrm{f}$ & $\%$ \\
\hline Positive Feelings & 16 & 100 \\
I felt excited & 14 & 88 \\
I felt like an adult & 14 & 88 \\
I felt successful & 9 & 57 \\
I felt fearless about sharing my ideas & 7 & 44 \\
I wanted to do it again & 5 & 32 \\
I felt brave & 5 & 32 \\
I trusted myself & & \\
\hline Negative Feelings & 0 & 0 \\
No negative opinion & & \\
\hline
\end{tabular}

Analysis of the 5th question showed that participants' ideas about ALASTs' presentations had a positive perspective. They described their feelings about presentation process with "Excited" and "Successful". For instance, S3 mentioned that "I felt really excited and thought that I can direct a movie again, I trust myself. With my friends, we will film a movie. Maybe, about animals or an experiment."

Another remarkable answer is S21's that is shown below:

"I'm kind a shy especially in this kind of activities, but this time something was different. I felt fearless to share my ideas, because this time I was not alone and we really did our best."

Also they made point of their feelings about being an adult. With ALASTs, they feel more confident and had courage to share their ideas with adults. For example, S12's answer is shown below;

"Yes I always like science, but when I began filming it was really different than before, because I found an opportunity as acting adults and I was free to do what I want. I felt myself like an excited.

Question 6: What do you think when you consider the entire process with ALASTs? How did ALASTs affect your opinions about authentic learning, science and technology?

Purpose of asking this question was trying to understand students' opinions about entire process with ALASTs. Answers of question were divided into two themes first. These categories were "Efficient" and "Inefficient". There were 8 different codes in efficient themes and 2 codes in negative themes. Analysis of the sixth question is summarized in the Table 12.
Table 12. The Quantitative Analysis of the Interview Question 6

\begin{tabular}{|l|c|c|}
\hline Themes and Codes & $\mathrm{f}$ & $\%$ \\
\hline Efficient & & \\
I learned easily & 10 & 63 \\
I liked authentic activities & 7 & 44 \\
They surprised me & 7 & 44 \\
I wanted to attend the lesson & 9 & 57 \\
I wanted to study science & 6 & 38 \\
I learned with fun & 6 & 38 \\
I felt confident & 4 & 25 \\
I got excited & 1 & 7 \\
\hline Inefficient & & \\
Time-consuming & 4 & 25 \\
Tiring & 2 & 13 \\
\hline
\end{tabular}

When the sixth question was analyzed, it was seen that engagement of the students to the technology integrated courses had positive perspective. According to the students' interview analyses, $44 \%$ of the students found the process as surprising. They also wanted to attend science course more than previous science courses. Furthermore students' desires towards studying science increased. Some of the students' statements were remarkable. Their ideas about using technology in science courses changed to a positive perspective. S8's and S23's answers are respectively specified below as an example:

"Before these activities, I thought that I can use internet for doing homework or gaming. But now I can search libraries online and I can assemble videos. I have even known how to edit a picture. With the help of this process, I can learn easier."

"I was worried at first, because I encountered so much new concepts. At least, they were new for me. But I learned easier than I guess. I didn't feel as doing homework."

In contrast, the process is regarded as time taking and amusing. S12's answer is as follows:

"It took too much time for me to do my duties and I felt tired."

Question 7: What did you gain from these activities? Did the activities make your knowledge more permanent?

Purpose of asking this question was trying to understand students' feelings about the ALASTs' presentations. Answers of question were divided into two themes. These themes were "Useful" and "Useless". There were 5 different codes in useful themes and 1 code in negative category. Analysis of the 7th question is summarized in the Table 13.

Table 13. The Quantitative Analysis of the Interview Question 7

\begin{tabular}{|l|c|c|}
\hline Themes and Codes & $\mathrm{f}$ & $\%$ \\
\hline Useful & & \\
I understood the concepts better & 15 & 94 \\
I learned entertainingly & 12 & 75 \\
I learned working cooperatively & 8 & 50 \\
I learned easily & 7 & 44 \\
I learned through experience & 5 & 32 \\
\hline Useless & & \\
It didn't help me to learn & 1 & 7 \\
\hline
\end{tabular}


Analysis of 7th question revealed that students' opinions about ALASTs and its effect on learning science subjects had positive perspectives. They described their impressions with the word "Better". They also mentioned that their learning improved and they learned easier with ALASTs. Answers of S2 and S27 are cited as follows:

"It was really fun when I started to write my part (Structure of atoms) on newspaper; I can easily remember the symbols of atoms."

"These three activities helped me more than I thought for learning science. I have new experiences and learning with them makes learning better for me."

However S15 expressed his ideas express that "It didn't help me to learn.". When we asked to understand the reason of his answer, S15 indicated that "They are enjoyable but they are same with our previous lessons and I think that it didn't help to learn.".

\section{Conclusion and Discussion}

The main purpose of this study is to investigate the effect of using ALASTs in science courses on 7th grade students' opinions about authentic learning process and technology use been necessary for designing activities in science courses. In this study, qualitative research design was used. We used semi-structure interview method to investigate students' opinions. ALASTs were applied during 9 weeks and at the end of the implementation, a semi-structured interview performed with 16 students. These activities were "Publishing a Newspaper", "Filming a Short Movie" and "Preparing a Mini Symposium" that were suggested by [45] to integrate technology into the science courses.

Based on results of interview questions analyses, we can determine that ALASTs developed through a positive tendency about students' technology use such as searching online libraries, understanding the process of publishing a newspaper, planning a mini symposium, writing a short movie script, etc. Also, we can say that students' opinions towards attending the course improved with ALASTs. According to these findings, it can be stated that these activities are effective on students' willing about participating in the science courses. Current study's results are similar with the literature [10], [37].

We can also determine that students can learn easily and entertainingly with ALASTs. This result is an accord with the literature. For example, according to [48], [49], an authentic learning environment has a sense of diversity for learning and these kinds of rich learning environments are more effective on students' motivation about participating courses in the classroom and helpful for developing individual skills [50]. We can say that the reason of this result is that students were free to control their learning process in our study and by this means they learned how they can be a part of learning. This result is supported with the other researchers. For example, [4] stated that authentic learning environments offer a sense of personal control about what the learner learns and how the learner learns.

ALASTs also contributed to students' individual learning. Participants determined that they feel free to express their thoughts clearly. They also introduced themselves as important and brave. The reasons for this can be explained with the way that students gained self-confidence with ALASTs and they expressed themselves freely [4]. It can be indicated that students cooperated with each other when they prepared and published their newspaper and distributed it from the beginning till the end. Thanks to this activity, students joined arguments and they worked collaboratively. Their self-confidence developed with this process.

Another remarkable result is that students experienced like scientists, while they were working with their small groups. Since the groups were determined based on their interests, they came together just like scientists who are doing research [50].

We can also determine that participants' ways to apply science in daily lives by using the ALASTs. The activities such as publishing a newspaper, filming a short movie and preparing a mini symposium are the activities that can be seen out of school life. Students' answers revealed that science courses transform a new version been more interesting and effective with the implementation. This result possibly derived from living 'real-world' experiences chances that are presented by ALASTs to students [19].

Furthermore, students defined themselves as directors and reporters and they used the words such as "famous reporters" and "famous directors" to explain how they felt in the process. Additionally, they mentioned about their future works with the same words. Due to this outcome, ALASTs give participants to have a chance to experience different daily life problems and also ALASTs can affect their future work choices [19], [31], [32]. Since authentic problems are utilized with technology, they help students to solve real world problems without harms.

\section{REFERENCES}

[1] Topçu, H., Küçük, S., \& Göktaş, Y. (2014). Sınıf Öğretmeni Adaylarının İlköğretim Matematik Öğretiminde Eğitsel Bilgisayar Oyunlarının Kullanımına Yönelik Görüşleri. Turkish Journal of Computer and Mathematics Education Vol, 5(2), 119-136.

[2] Gulikers, J. T., Bastiaens, T. J., \& Martens, R. L. (2005). The surplus value of an authentic learning environment. Computers in Human Behavior, 21(3), 509-521.

[3] Herrington, J., \& Kervin, L. (2007). Authentic learning supported by technology: Ten suggestions and cases of integration in classrooms. Educational Media International, 44(3), 219-236.

[4] Watters, J. J., \& Ginns, I. S. (2000). Developing motivation to 
teach elementary science: Effect of collaborative and authentic learning practices in preservice education. Journal of Science Teacher Education, 11(4), 301-321.

[5] Edelson, D. C. (1998). Realising authentic science learning through the adaptation of scientific practice. International handbook of science education, 1, 317-331.

[6] Finch, J. L., \& Jefferson, R. N. (2013). Designing Authentic Learning Tasks for Online Library Instruction. The Journal of Academic Librarianship, 39(2), 181-188.

[7] Herrington, J., Reeves, T. C., \& Oliver, R. (2007). Immersive learning technologies: Realism and online authentic learning. Journal of Computing in Higher Education, 19(1), 80-99.

[8] Lee, H. S., \& Butler, N. (2003). Making authentic science accessible to students. International Journal of Science Education, 25(8), 923-948.

[9] Herrington, J. (2006). Authentic e-learning in higher education: Design principles for authentic learning environments and tasks.

[10] Herrington, J., Oliver, R., \& Reeves, T. C. (2002). Patterns of engagement in authentic online learning environments.

[11] Yukawa, J., \& Harada, V. H. (2011). Authentic Learning Is Not Just for Students: It's for Librarians, Too!. School Library Monthly, 27(4), 5-8.

[12] Laur, D. (2013). Authentic learning experiences: A real-world approach to project-based learning. Routledge

[13] van Joolingen, W. R., de Jong, T., Lazonder, A. W., Savelsbergh, E. R., \& Manlove, S. (2005). Co-Lab: research and development of an online learning environment for collaborative scientific discovery learning. Computers in human behavior, 21(4), 671-688.

[14] Parker, J., Maor, D., \& Herrington, J. (2013). Authentic online learning: Aligning learner needs pedagogy and technology. Issues in Educational Research, 23(2), 227-241.

[15] Petraglia, J. (1998). Reality by design: The rhetoric and technology of authenticity in education. Routledge

[16] Reeves, T. C., Herrington, J., \& Oliver, R. (2002). Authentic activities and online learning. Western Australia pp. 562-567

[17] Jonassen, D. H. (1999). Designing constructivist learning environments. Instructional design theories and models: A new paradigm of instructional theory, 2, 215-239.

[18] Herrington, J., Reeves, T. C., Oliver, R., \& Woo, Y. (2004). Designing authentic activities in web-based courses. Journal of Computing in Higher Education, 16(1), 3-29.

[19] Stein, S. J., Isaacs, G., \& Andrews, T. (2004). Incorporating authentic learning experiences within a university course. Studies in Higher Education, 29(2), 239-258.

[20] Knobloch, N. A. (2003). Is experiential learning authentic?. Journal of Agricultural Education, 44(4), 22-34.

[21] Lombardi, M. M. (2007). Authentic learning for the $21 \mathrm{st}$ century: An overview. Educause learning initiative, 1(2007), $1-12$.

[22] Sugarman, S. D., \& Widess, E. G. (1974). Equal protection for non-English-speaking school children: Lau v. Nichols.
California Law Review, 62(1), 157-182.

[23] Herrington, J., Parker, J., \& Boase-Jelinek, D. (2014). Connected authentic learning: Reflection and intentional learning. Australian Journal of Education, 0004944113517830 .

[24] Cho, Y. H., Caleon, I. S., \& Kapur, M. (2015). Authentic Problem Solving and Learning in the 21 st Century.

[25] Brown, J. S., Collins, A., \& Duguid, P. (1989). Situated cognition and the culture of learning. Educational researcher, $18(1), 32-42$.

[26] Wiggins, G. (1990). The Case for Authentic Assessment. ERIC Digest.

[27] Herrington, J., Reeves, T. C., \& Oliver, R. (2010). A practical guide to authentic e-learning. Routledge

[28] Gobert, J. A, (2002) WISE Inquiry Project for Students' East-West Coast Collaborationl Janice Gobert Jim Slotta Amy Pallant The Concord Consortium UC-Berkeley The Concord Consortium Sandra Nagy \& Elliot Targum Harvard University.

[29] Newmann, F. M. (1991). Linking restructuring to authentic student achievement. Phi Delta Kappan, 72(6), 458-463.

[30] Savery, J. R., \& Duffy, T. M. (1995). Problem based learning: An instructional model and its constructivist framework. Educational technology, 35(5), 31-38.

[31] Braund, M., \& Reiss, M. (2006). Towards a more authentic science curriculum: The contribution of out-of-school learning. International Journal of Science Education, 28(12), 1373-1388.

[32] Slepkov, H. (2008). Teacher professional growth in an authentic learning environment. Journal of Research on Technology in Education, 41(1), 85-111.

[33] Banas, J. R., \& York, C. S. (2014). Authentic learning exercises as a means to influence preservice teachers' technology integration self-efficacy and intentions to integrate technology. Australasian Journal of Educational Technology, 30(6), 728-746.

[34] Herrington, J., \& Oliver, R. (2000). An instructional design framework for authentic learning environments. Educational technology research and development, 48(3), 23-48

[35] Herrington, J. A. (2005). Authentic tasks in e-learning designs.

[36] Herrington, J., Reeves, T. C., \& Oliver, R. (2014). Authentic learning environments. In Handbook of research on educational communications and technology (pp. 401-412). Springer New York.

[37] Herrington, A., \& Herrington, J. (2007). Authentic mobile learning in higher education.

[38] Woo, Y., Herrington, J. A., Agostinho, S., \& Reeves, T. C. (2007). Implementing authentic tasks in web-based learning environments.

[39] Cholewinski, M. (2009). An introduction to constructivism and authentic activity. Journal of The School of Contemporary International Studies Nagoya University of Foreign Studies, 5, 283-316.

[40] Gilbert, J. K. (2004). Models and modelling: Routes to more 
authentic science education. International Journal of Science and Mathematics Education, 2(2), 115-130.

[41] Bolin, A. U., Khramtsova, I., \& Saarnio, D. (2005). Using student journals to stimulate authentic learning: Balancing Bloom's cognitive and affective domains. Teaching of Psychology, 32(3), 154-159.

[42] Yıldırım, A., Simșek, H. (2013), Sosyal Bilimlerde Nitel Araştırma Yöntemleri, Seçkin Yayıncılık, Ankara

[43] Strauss, A., Corbin, J. (1990). Basics of Qualitative Research: Grounded Theory Procedures and Techniques. New Delhi: SAGE Publications.

[44] Turkish Ministry of National Education, (2013), https://ttkb.meb.gov.tr/ 18.09.2016

[45] Harris, J., Mishra, P., \& Koehler, M. (2009). Teachers' technological pedagogical content knowledge and learning activity types: Curriculum-based technology integration reframed. Journal of Research on Technology in Education, 41(4), 393-416.

[46] Driver, R., Newton, P., \& Osborne, J. (2000). Establishing the

${ }^{i}$ This study is formed from first author's doctoral dissertation prepared with consultancy of second author. norms of scientific argumentation in classrooms. Science education, 84(3), 287-312.

[47] Erduran, S., Simon, S., \& Osborne, J. (2004). TAPping into argumentation: Developments in the application of Toulmin's argument pattern for studying science discourse. Science education, 88(6), 915-933.

[48] Barraclough, A., \& Guymer, I. (1998). Virtual reality-a role in environmental engineering education?. Water Science and Technology, 38(11), 303-310.

[49] Chittaro, L., \& Ranon, R. (2007). Web3D technologies in learning, education and training: Motivations, issues, opportunities. Computers \& Education, 49(1), 3-18.

[50] Kaya, O. N., Yager, R., \& Dogan, A. (2009). Changes in attitudes towards science-technology-society of pre-service science teachers. Research in Science Education, 39(2), 257-279.

[51] Koenig, Judith A. (2011). Assessing 21st Century skills: Summary of a workshop. Washington, DC: National Research Council. 